DOI:10.17951/h.2020.54.3.79-89

\begin{tabular}{lcc}
\hline \multicolumn{3}{c}{ A N N A L E S } \\
UNIVERSITATIS MARIAE CURIE-SKŁODOWSKA \\
LUBLIN - POLONIA \\
VOL. LIV, 3 & SECTIOH \\
\hline
\end{tabular}

\author{
ANNA NOWAK \\ anna.nowak@up.lublin.pl \\ Uniwersytet Przyrodniczy w Lublinie. Wydział Agrobioinżynierii \\ ul. Akademicka 13, 20-950 Lublin \\ ORCID ID: https://orcid.org/0000-0003-1741-8692
}

\title{
Produktywność pracy $w$ gospodarstwach rolnych $w$ Polsce w zależności od ich wielkości ekonomicznej
}

Labour Productivity of Farms in Poland Depending on Their Economic Size

Keywords: labour productivity; farms; economic size of farm

Słowa kluczowe: produktywność pracy; gospodarstwa rolne; wielkość ekonomiczna gospodarstwa

JEL: D24; Q18; Q12

Propozycja cytowania: Nowak, A. (2020). Produktywność pracy w gospodarstwach rolnych w Polsce w zależności od ich wielkości ekonomicznej. Annales Universitatis Mariae Curie-Skłodowska, sectio H - Oeconomia, Vol. 54, No. 3.

\footnotetext{
Abstract

Theoretical background: The paper deals with issues related to labour productivity of farms. Productivity is connected with the optimum utilisation of the farm's resources. The significance of studies on labour productivity can be attributed to the fact that it is one of the conditions for development and improvement of business competitiveness. Farms in Poland are highly differentiated; hence, economic analyses should be carried out for uniform groups.

Purpose of the article: Assessment of labour productivity for farms of different economic size.

Research methods: The study was carried out based on data from the European system for collecting accounting data on farms, i.e. FADN. The subjective scope of the study was Polish farms and the time span was 2010-2017. The analysis took into account six classes of economic size based on standard production value. Labour productivity was evaluated using partial productivity indicators.
} 
Main findings: The study showed a relationship between labour productivity and economic size of farms. In classes from 1 to 5 over all the analysed years, a growth in productivity was recorded resulting in successive upgrading of the farms to higher classes. The economically strongest farms had lower labour productivity than farms in class 5. This should be attributed to a higher share of less intensive crops in the structure of crops for this group of farms. It was demonstrated that the economically weakest farms, i.e. with standard production ranging from 2 to 8 thousand euro, achieved the lowest level of labour productivity. In 2017, it was only $23.7 \%$ of its average level for the whole population of farms covered by the study. This means that the economic power of farms determined effective utilisation of the labour factor. The studies also confirmed a relationship between the level of labour productivity and the level of technical resources. On the one hand, it points to a need for optimising the labour resources in agriculture, while on the other - to the necessity of implementing modernisation processes. The studies provide grounds for further research that should take into account a wider scope of determinants of improvement in the effective utilisation of the labour factor.

\begin{abstract}
Abstrakt
Uzasadnienie teoretyczne: Opracowanie dotyczy problematyki produktywności pracy w gospodarstwach rolnych. Produktywność wiąże się z optymalnym wykorzystaniem zasobów gospodarstwa rolnego. Znaczenie badań nad produktywnością pracy wynika $\mathrm{z}$ tego, że stanowi ona jeden z warunków rozwoju i poprawy konkurencyjności przedsiębiorstw. Gospodarstwa rolne w Polsce charakteryzują się dużym zróżnicowaniem, stąd zasadne jest prowadzenie analiz ekonomicznych dla bardziej jednorodnych grup.

Cel artykułu: Ocena produktywności pracy w gospodarstwach rolnych należących do różnych klas wielkości ekonomicznej.

Metody badawcze: Badania zrealizowano na podstawie danych europejskiego systemu zbierania danych rachunkowych z gospodarstw rolnych, tj. FADN. Zakres podmiotowy badań obejmował gospodarstwa rolne w Polsce, zakres czasowy dotyczył lat 2010-2017. W analizie uwzględniono sześć klas wielkości ekonomicznej gospodarstw rolnych, wyodrębnionych w oparciu o wartość produkcji standardowej. Ocenę produktywności pracy przeprowadzono z wykorzystaniem cząstkowych wskaźników produktywności.

Główne wnioski: Badania wykazały zależność produktywności pracy od wielkości ekonomicznej gospodarstw rolnych. W klasach od 1 do 5 we wszystkich badanych latach miał miejsce wzrost produktywności wraz z przechodzeniem do coraz wyższej klasy. W gospodarstwach najsilniejszych ekonomicznie produktywność pracy była niższa niż w klasie 5. Należy to tłumaczyć większym udziałem mniej intensywnych upraw w strukturze zasiewów tej grupy gospodarstw. Wykazano, że gospodarstwa najsłabsze ekonomicznie, tj. wytwarzające od 2 do 8 tys. euro produkcji standardowej, osiągały najniższy poziom produktywności pracy. W 2017 r. stanowiła ona zaledwie 23,7\% średniego jej poziomu dla całej populacji badanych gospodarstw rolnych. Oznacza to, że siła ekonomiczna gospodarstw determinowała efektywność wykorzystania czynnika pracy. Badania potwierdziły również związek poziomu produktywności pracy z poziomem jej technicznego uzbrojenia. Wskazuje to z jednej strony na potrzebę optymalizacji zasobów pracy w rolnictwie, $\mathrm{z}$ drugiej zaś na konieczność procesów modernizacyjnych. Przeprowadzone badania stanowią podstawę do dalszych badań, które powinny uwzględniać większy zakres determinant poprawy efektywności wykorzystania czynnika pracy.
\end{abstract}

\title{
Wprowadzenie
}

Produktywność określana jest jako zdolność czynników produkcji do tworzenia efektu w postaci produkcji (Latruffe, 2010, s. 18). Komisja Europejska uważa produktywność za najbardziej wiarygodny wskaźnik konkurencyjności w perspektywie długoterminowej (European Commission, 2009, s. 7). Szczególnie istotną rolę przy- 
pisuje się produktywności pracy, której poziom i wzrost stanowią centralny punkt w ekonomii i wyznaczają implicite wyższy poziom dobrobytu (Góral \& Rembisz, 2017, s. 17). Wysoka produktywność pracy jest bardzo ważna zarówno dla całej gospodarki, jak i dla poszczególnych przedsiębiorstw. Dotyczy to również sektora rolnego oraz poszczególnych jego podmiotów, tj. gospodarstw rolnych.

Gospodarstwa rolne w Polsce charakteryzują się dużym zróżnicowaniem. Dotyczy ono posiadanego potencjału produkcyjnego oraz efektywności jego wykorzystania. Z tego względu bardzo ważną rolę odgrywa segmentacja gospodarstw, pozwala bowiem na opracowywanie strategii rozwoju grup gospodarstw, a szczególnie ich strategii konkurowania (Niezgoda, 2009a, s. 156). Jednym z podziałów gospodarstw jest klasyfikacja uwzględniająca wielkość ekonomiczną, wskazującą na ich potencjalne możliwości wytwórcze. Uwzględnienie w badaniach takiej klasyfikacji pozwala na analizę bardziej jednorodnych grup oraz porównywanie ich pomiędzy sobą.

Biorąc pod uwagę znaczenie produktywności pracy oraz poszukiwania sposobów jej wzrostu, za cel niniejszego opracowania przyjęto ocenę produktywności pracy w polskich gospodarstwach rolnych należących do różnych klas wielkości ekonomicznej.

\section{Przegląd literatury}

Produktywność pracy wiąże się z optymalnym wykorzystaniem zasobów gospodarstwa rolnego. Przegląd literatury pozwala stwierdzić, że kształtowana jest ona przez zespół takich czynników, jak techniczne uzbrojenie pracy, powierzchnia użytków rolnych (UR) przypadająca na zatrudnionego, poziom przygotowania zawodowego rolników czy organizacja pracy (Czyżewski \& Kryszak, 2016, s. 155-165; Kusz \& Misiak, 2017, s. 145-150). Z badań wielu autorów wynika, że poziom produktywności pracy w polskim rolnictwie jest zróżnicowany i wciąż niższy od tego obserwowanego poza rolnictwem. Jest to efekt zbyt wysokiego zatrudnienia w tym sektorze (Mrówczyńska-Kamińska, 2012, s. 68-76). Warto nadmienić, że w 2017 r. w rolnictwie zatrudnionych było $15,5 \%$ ogółu pracujących w gospodarce, podczas gdy udział tego sektora $\mathrm{w}$ wartości dodanej brutto stanowił zaledwie 2,6\% (GUS, 2018b, s. 246, 497). Wysokie zasoby pracy stanowią więc z jednej strony o potencjale rozwoju rolnictwa, $\mathrm{z}$ drugiej zaś ograniczają dynamikę procesów modernizacyjnych w rolnictwie (Wicki, 2016, s. 149-160).

Produktywność w rolnictwie można obliczać jako produktywność cząstkową, dotyczącą jednego czynnika produkcji, lub jako produktywność całkowitą. Wiele opracowań naukowych podejmuje problematykę produktywności z wykorzystaniem wskaźników produktywności całkowitej (Čechura, Grau, Hockmann, Kroupová, \& Levkovych, 2014, s. 9-58; Bokusheva \& Čechura, 2017, s. 16-25; Madau, Furesi, \& Pietro, 2017, s. 1-14). Badania produktywności jednego z czynników produkcji, tj. czynnika pracy, odnaleźć można w wielu pracach naukowych. Dotyczą one jednak 
najczęściej albo sektora rolnego (Gołaś, 2010, s. 19-42), albo ogółu gospodarstw rolnych (Sobczyński, 2010, s. 244-257; Nowak \& Kijek, 2016, s. 16-21). Niektóre analizy obejmują poszczególne typy rolnicze gospodarstw, wydzielone ze względu na kierunek produkcji (Mikołajczyk, 2011, s. 193-198). Rzadziej spotykane są badania dotyczące produktywności pracy w gospodarstwach rolnych różnych pod względem wielkości ekonomicznej. Badania takie w odniesieniu do gospodarstw czeskich przeprowadzili Novotná i Volek (2016, s. 333-340). Wykazały one, że wielkość gospodarstwa ma znaczący wpływ na poziom produktywności pracy. Efektywność czynników produkcji (w tym czynnika pracy) polskich gospodarstw rolnych w latach 2010-2013 analizowała Orłowska (2014, s. 163-169). Wykazała, że im większe ekonomicznie było gospodarstwo, tym wyższą charakteryzowało się produktywnością ziemi, pracy i kapitału (z wyjątkiem gospodarstw bardzo dużych). Jak wynika z danych GUS (2018a, s. 89-95) oraz z badań innych autorów (Jezierska-Thöle, 2012, s. 45-64; Orłowska, 2014, s. 163-169), gospodarstwa rolne w Polsce są silnie zróżnicowane, zarówno pod względem powierzchni, jak i wielkości ekonomicznej. Stąd zasadne jest prowadzenie analiz ekonomicznych w odniesieniu do bardziej jednorodnych grup.

\section{Metody badawcze}

Badania zrealizowano na podstawie wyników standardowych europejskiego systemu zbierania danych rachunkowych z gospodarstw rolnych FADN (Farm Accountancy Data Network). Zaletą stosowania zunifikowanych baz danych jest możliwość przeprowadzenia oceny gospodarowania bardziej jednorodnych grup gospodarstw oraz porównania ich między sobą - między krajami i regionami (Grochowska \& Mańko, 2014, s. 25-33). W 2017 r. w zbiorze gospodarstw rolnych uczestniczących w polskim FADN znajdowało się 12293 gospodarstw, natomiast w 2010 r. - 11191.

W ramach przyjętego kryterium grupowania gospodarstwa podzielono ze względu na wielkość ekonomiczną, określaną sumą wartości standardowej produkcji (SO) wszystkich działalności występujących w gospodarstwie rolniczym, wyrażonej w euro. Produkcja standardowa jest miernikiem potencjalnych możliwości wytwórczych. Jest to średnia wartość produkcji określonej działalności rolniczej z 5 lat, uzyskana z 1 ha lub od 1 zwierzęcia w ciągu 1 roku, w przeciętnych dla danego regionu warunkach produkcyjnych (Floriańczyk, Osuch, \& Płonka, 2018, s. 10). Wyodrębnia się następujące klasy wielkości ekonomicznej gospodarstw w zależności od całkowitej wartości standardowej produkcji: klasa 1 - bardzo małe (2-8 tys. euro), klasa 2 - małe ( $8-25$ tys. euro), klasa 3 - średnio-małe (25-50 tys. euro), klasa 4 średnio-duże (50-100 tys. euro), klasa 5 - duże (100-500 tys. euro), klasa 6 - bardzo duże ( $\geq 500$ tys. euro) (Floriańczyk i in., 2018, s. 10). Przyjęto hipotezę, że wyżej wymienione grupy gospodarstw rolnych różnią się poziomem produktywności pracy.

Analizę produktywności pracy przeprowadzono na podstawie cząstkowych wskaźników produktywności czynnika pracy wyrażonych wartością dodaną brutto 
przypadającą na 1 osobę pełnozatrudnioną (Annual Work Unit, AWU) w gospodarstwie rolnym. Dodatkowo policzono wskaźnik będący relacją wartości produkcji rolniczej oraz nakładów pracy w gospodarstwie rolnym wyrażonych w godzinach. W analizie uwzględniono również wybrane charakterystyki badanych grup gospodarstw, tj. średnią powierzchnię użytków rolnych (UR), uzbrojenie ziemi w pracę wyrażone liczbą pracujących na 100 ha UR, dochód z rodzinnego gospodarstwa rolnego przypadający na 1 ha UR, a także wskaźnik technicznego uzbrojenia pracy będący relacją wartości aktywów trwałych gospodarstwa do liczby osób pełnozatrudnionych. Do analizy zmian w czasie wykorzystano wskaźniki dynamiki oraz średnioroczne tempo zmian zjawiska w czasie, obliczone jako średnia geometryczna $\mathrm{z}$ indeksów łancuchowych.

Badaniami objęto lata 2010-2017, co było zdeterminowane zmianą metodyki wyodrębniania klas wielkości ekonomicznej gospodarstw rolnych od $2010 \mathrm{r}$. Uwzględnienie w badaniach wcześniejszych lat uniemożliwiłoby porównywalność analizowanych wskaźników pomiędzy grupami gospodarstw.

\section{Wyniki}

W tabeli 1 przedstawiono wybrane cechy gospodarstw rolnych badanych klas wielkości ekonomicznej dla dwóch skrajnych lat badań. Wynika z niej, że gospodarstwa należące do poszczególnych klas zróżnicowane były pod względem średniej powierzchni UR. Powierzchnia ta rosła wraz z przechodzeniem do wyższej klasy wielkości ekonomicznej. W 2017 r. wahała się od 7,6 ha w gospodarstwach o najmniejszym potencjale ekonomicznym do 557,6 ha w gospodarstwach najsilniejszych ekonomicznie. Marcysiak i Marcysiak (2015, s. 166-171) podkreślają, że powierzchnia użytków rolnych gospodarstwa determinuje kształtowanie się podstawowych relacji produkcyjno-ekonomicznych, co w efekcie znajduje odzwierciedlenie w uzyskiwanych dochodach. Odwrotną tendencję obserwuje się w przypadku liczby pracujących w przeliczeniu na 100 ha UR, zmniejszała się ona bowiem wraz ze wzrostem klasy wielkości ekonomicznej. Wynika to z tego, że większy rozmiar produkcji wymusza stosowanie pracooszczędnych technik i bardziej intensywnych technologii wytwarzania produktów rolniczych (Skarżyńska, 2019, s. 100-120). Średnia dochodowość ziemi, wyrażona wartością dochodu z gospodarstwa rolnego przypadającego na 1 ha UR, wynosiła 540,3 euro/ha oraz 508,1 euro/ha, odpowiednio w latach 2010 i 2017. Wyższym klasom wielkości ekonomicznej towarzyszyła wyższa wartość tego wskaźnika. Wyjątek stanowiła w 2010 r. klasa 6, a w 2017 r. - klasy 5 i 6, gdzie dochodowość była niższa niż w poprzedniej klasie gospodarstw. W klasie $1 \mathrm{w} 2017$ r. zaobserwowano znaczny spadek dochodowości ziemi w stosunku do $2010 \mathrm{r}$. Tendencja taka ma miejsce od 2012 r. Należy to thumaczyć tym, że gospodarstwa o niskim potencjale ekonomicznym nie miały takich szans rozwoju w badanym okresie, jak gospodarstwa silniejsze. Średnia wartość inwestycji brutto 
przypadająca na 1 gospodarstwo w tej klasie w 2017 r. wynosiła jedynie 22 euro, przy przeciętnej ich wartości w całej populacji gospodarstw wynoszącej 3582 euro. W 2010 r. sytuacja była podobna (FADN EU Database). Zróżnicowanie uzyskiwanego $\mathrm{w}$ gospodarstwach dochodu ma z kolei istotny wpływ na możliwości ich wzrostu i rozwoju. Od poziomu dochodu zależy też kształtowanie się indywidualnych krzywych popytu na czynniki produkcji oraz podaży, ilustrujące ofertę rynkową wytwarzanych w gospodarstwie produktów. Przyczyn różnicujących wyniki produkcyjne oraz poziom dochodów pomiędzy gospodarstwami rolnymi należy poszukiwać w zasobach czynników produkcji, stosowanych technologiach, a także w czynniku wiedzy (Niezgoda, 2009b, s. 24-37).

Tabela 1. Wybrane wskaźniki charakteryzujące gospodarstwa rolne różnych klas wielkości ekonomicznej w latach 2010 i 2017

\begin{tabular}{|l|c|c|c|c|c|c|}
\hline \multirow{2}{*}{$\begin{array}{c}\text { Wielkość } \\
\text { ekonomiczna }\end{array}$} & \multicolumn{2}{|c|}{$\begin{array}{c}\text { Średnia powierzchnia UR } \\
\text { (ha) }\end{array}$} & \multicolumn{2}{c|}{$\begin{array}{c}\text { Liczba osób } \\
\text { pełnozatrudnionych na 100 } \\
\text { ha UR (AWU/100 ha) }\end{array}$} & \multicolumn{2}{c|}{ Dochód na 1 ha UR (euro/ha) } \\
\cline { 2 - 7 } & 2010 & 2017 & 2010 & 2017 & 2010 & 2017 \\
\hline Klasa 1 & 7,8 & 7,6 & 16,1 & 15,6 & 410,5 & 231,0 \\
\hline Klasa 2 & 13,3 & 14,0 & 11,9 & 10,9 & 488,4 & 403,0 \\
\hline Klasa 3 & 26,7 & 23,9 & 7,6 & 7,7 & 637,6 & 643,3 \\
\hline Klasa 4 & 46,4 & 39,5 & 5,1 & 5,3 & 703,3 & 777,1 \\
\hline Klasa 5 & 103,8 & 86,2 & 4,1 & 3,7 & 706,9 & 726,5 \\
\hline Klasa 6 & 641,3 & 557,6 & 3,7 & 3,4 & 312,9 & 248,7 \\
\hline Ogółem & 18,5 & 19,0 & 9,1 & 8,4 & 540,3 & 508,1 \\
\hline
\end{tabular}

Źródło: opracowanie własne na podstawie bazy danych FADN EU.

Wskaźnik produktywności pracy obliczono jako relację wartości dodanej brutto do liczby osób pełnozatrudnionych. Wartość dodana jest jedną z najbardziej zobiektywizowanych kategorii oceny efektywności przedsiębiorstw stosowanych w ocenie produktywności pracy (Gołaś, 2010, s. 19-42). Tak obliczony wskaźnik produktywności cząstkowej zróżnicowany był zarówno pomiędzy klasami, jak i w latach (tabela 2). W klasach od 1 do 3 zaobserwowano spadek poziomu produktywności pracy w latach 2010-2017. Średnioroczny spadek jej poziomu wynosił 6,24\%, 0,73\% oraz $0,04 \%$, odpowiednio w klasach od 1 do 3 . W pozostałych grupach gospodarstw miał miejsce wzrost poziomu produktywności pracy. Analizując poszczególne grupy gospodarstw, należy stwierdzić, że w klasach od 1 do 5 we wszystkich badanych latach wystąpił wzrost produktywności wraz z przechodzeniem do coraz wyższej klasy. W gospodarstwach najsilniejszych ekonomicznie produktywność pracy była niższa niż w klasie 5. Należy to tłumaczyć większym udziałem mniej intensywnych upraw w strukturze zasiewów tej grupy gospodarstw. 
Pobrane z czasopisma Annales H - Oeconomia http://oeconomia.annales.umcs.pl

Data: 26/04/2023 13:31:40

PRODUKTYWNOŚĆ PRACY W GOSPODARSTWACH ROLNYCH W POLSCE...

Tabela 2. Produktywność pracy w gospodarstwach rolnych różnych klas wielkości ekonomicznej w latach 2010-2017 (euro/AWU)

\begin{tabular}{|l|c|c|c|c|c|c|c|}
\hline \multirow{2}{*}{ Lata } & \multicolumn{7}{|c|}{ Wartość dodana brutto na 1 AWU (euro/AWU) } \\
\cline { 2 - 9 } & Klasa 1 & Klasa 2 & Klasa 3 & Klasa 4 & Klasa 5 & Klasa 6 & Ogółem \\
\hline 2010 & 2743,7 & 4478,5 & 9278,7 & 15410,5 & 21598,4 & 18606,3 & 7056,5 \\
\hline 2011 & 2846,2 & 4827,2 & 10189,1 & 16256,7 & 22177,3 & 18844,9 & 7443,0 \\
\hline 2012 & 2600,8 & 4349,4 & 8743,7 & 14954,4 & 24121,7 & 19248,2 & 7497,1 \\
\hline 2013 & 2280,0 & 4191,4 & 8055,8 & 13938,8 & 23245,8 & 19571,3 & 7002,4 \\
\hline 2014 & 1873,4 & 3566,0 & 7194,8 & 13190,1 & 23546,0 & 19378,4 & 6437,7 \\
\hline 2015 & 1573,1 & 3701,3 & 6866,5 & 12067,4 & 20335,3 & 17139,6 & 6053,0 \\
\hline 2016 & 1833,3 & 3501,9 & 6826,8 & 12020,6 & 20267,8 & 17489,1 & 5982,2 \\
\hline 2017 & 1747,9 & 4253,3 & 9250,5 & 16061,9 & 24195,0 & 20956,0 & 7383,1 \\
\hline $2010=100 \%$ & 63,7 & 95,0 & 99,7 & 104,2 & 112,0 & 112,6 & 104,6 \\
\hline $\begin{array}{l}\text { Średnioroczna } \\
\text { zmiana (\%) }\end{array}$ & $-6,24$ & $-0,73$ & $-0,04$ & 0,59 & 1,64 & 1,71 & 0,65 \\
\hline
\end{tabular}

Źródło: opracowanie własne na podstawie bazy danych FADN EU.

Badaniem objęto również relację wartości produkcji rolniczej do nakładów pracy wyrażonych w godzinach. W każdej z badanych klas odnotowano dodatnią dynamikę wzrostu analizowanego wskaźnika w latach 2010-2017 (tabela 3). Średnioroczny wzrost dla całej populacji gospodarstw wyniósł 2,53\%, najwyższy był w klasie 6 wielkości ekonomicznej. W klasie tej w każdym z badanych lat średnia wartość produkcji przypadającej na 1 godzinę pracy była najwyższa spośród wszystkich klas gospodarstw. W 2017 r. relacja wartości tego wskaźnika do jego poziomu w pozostałych klasach wynosiła: 13,$2 ; 7,6 ; 4,0 ; 2,3 ; 1,3$ - odpowiednio w klasach od 1 do 5 .

Tabela 3. Wartość produkcji w relacji do nakładów pracy ogółem w gospodarstwach rolnych różnych klas wielkości ekonomicznej w latach 2010-2017 (euro/godz.)

\begin{tabular}{|l|r|r|r|r|r|r|r|}
\hline \multirow{2}{*}{ Lata } & \multicolumn{6}{|c|}{ Wartość produkcji przypadajaca na 1 godz. nakładów pracy (euro/godz.) } \\
\cline { 2 - 8 } & Klasa 1 & Klasa 2 & Klasa 3 & Klasa 4 & Klasa 5 & Klasa 6 & Ogółem \\
\hline 2010 & 2,50 & 4,15 & 8,18 & 13,88 & 21,92 & 24,29 & 6,85 \\
\hline 2011 & 2,89 & 4,69 & 9,26 & 15,45 & 24,48 & 26,55 & 7,66 \\
\hline 2012 & 2,51 & 4,35 & 8,26 & 14,55 & 26,11 & 28,52 & 7,88 \\
\hline 2013 & 2,56 & 4,46 & 8,14 & 14,34 & 28,68 & 30,92 & 8,00 \\
\hline 2014 & 2,47 & 4,15 & 7,68 & 14,20 & 28,42 & 32,16 & 7,81 \\
\hline 2015 & 2,48 & 4,21 & 7,41 & 13,37 & 27,48 & 29,90 & 7,71 \\
\hline 2016 & 2,40 & 4,04 & 7,19 & 12,79 & 24,16 & 29,57 & 7,24 \\
\hline 2017 & 2,55 & 4,47 & 8,50 & 14,89 & 26,41 & 33,76 & 8,15 \\
\hline $2010=100 \%$ & 101,90 & 107,70 & 103,90 & 107,30 & 120,50 & 139,00 & 119,10 \\
\hline $\begin{array}{l}\text { Średnioroczny } \\
\text { wzrost (\%) }\end{array}$ & 0,26 & 1,06 & 0,55 & 1,01 & 2,70 & 4,81 & 2,53 \\
\hline
\end{tabular}

Źródło: opracowanie własne na podstawie bazy danych FADN EU.

Ocenie poddano techniczne uzbrojenie pracy, które obliczono jako relację wartości aktywów trwałych do liczby osób pełnozatrudnionych w gospodarstwie rolnym. $\mathrm{Z}$ danych zaprezentowanych $\mathrm{w}$ tabeli 4 wynika, że wraz ze wzrostem siły ekono- 
micznej gospodarstw rosło w nich techniczne uzbrojenie pracy. Wyjątek stanowiły gospodarstwa klasy 6, gdzie poziom wskaźnika był niższy niż w klasach 5 i 4 . Można zatem zauważyć zależność pomiędzy poziomem produktywności pracy i technicznego uzbrojenia w poszczególnych klasach wielkości ekonomicznej.

Tabela 4. Techniczne uzbrojenie pracy w gospodarstwach rolnych różnych klas wielkości ekonomicznej w latach 2010-2017 (euro/AWU)

\begin{tabular}{|l|r|r|r|r|r|r|c|}
\hline \multirow{2}{*}{ Lata } & \multicolumn{7}{|c|}{ Aktywa trwałe przypadające na 1 AWU (euro/AWU) } \\
\cline { 2 - 9 } & Klasa 1 & Klasa 2 & Klasa 3 & Klasa 4 & Klasa 5 & Klasa 6 & Ogółem \\
\hline 2010 & 50087,3 & 64555,7 & 101759,9 & 149765,4 & 145251,2 & 68872,1 & 77042,3 \\
\hline 2011 & 49063,8 & 64816,7 & 102886,6 & 145602,1 & 144444,0 & 68394,4 & 76483,1 \\
\hline 2012 & 43768,4 & 64669,2 & 96158,3 & 140275,4 & 171566,9 & 67283,1 & 78361,0 \\
\hline 2013 & 52265,6 & 70468,5 & 101439,6 & 149401,3 & 181823,5 & 73415,0 & 85602,9 \\
\hline 2014 & 55822,6 & 73484,9 & 106849,2 & 158700,5 & 191752,2 & 87599,8 & 90429,3 \\
\hline 2015 & 58194,1 & 75815,3 & 108695,3 & 162015,1 & 197196,1 & 82904,8 & 93045,1 \\
\hline 2016 & 57648,3 & 75209,0 & 108018,9 & 157165,0 & 192598,2 & 88109,5 & 91514,1 \\
\hline 2017 & 63623,5 & 82646,1 & 117689,1 & 165428,1 & 202129,2 & 100999,3 & 99183,1 \\
\hline $2010=100 \%$ & 127,0 & 128,0 & 115,7 & 110,5 & 139,2 & 146,6 & 128,7 \\
\hline $\begin{array}{l}\text { Średnioroczny } \\
\text { wzrost (\%) }\end{array}$ & 3,48 & 3,59 & 2,10 & 1,43 & 4,83 & 5,62 & 3,67 \\
\hline
\end{tabular}

Źródło: opracowanie własne na podstawie bazy danych FADN EU.

\section{Dyskusja wyników}

Produktywność pracy - obok produktywności ziemi i kapitału - stanowi cząstkową miarę efektywności produkcji, wykorzystywaną zarówno w analizach makroekonomicznych, jak i w ocenie sytuacji produkcyjno-gospodarczej poszczególnych jednostek czy grup jednostek. Dla producenta rolnego, który jest cenobiorcą, sposobem na wzrost dochodów jest poprawa efektywności wytwarzania (Rembisz \& Bezat-Jarzębowska, 2013, s. 9). Szczególna rola w tym względzie przypada czynnikowi pracy. Wzrost produktywności tego czynnika decyduje bowiem o przyjmowaniu przez producentów nowych technologii (Patra \& Nayak, 2012, s. 157-163).

Badania wykazały zależność produktywności pracy od wielkości ekonomicznej gospodarstw. Na podobne tendencje wzrostu produktywności pracy w miarę wzrostu siły ekonomicznej gospodarstw rolnych wskazują wyniki badań Abramczuk i in. (2016, s. 12-49) oraz Gałeckiej (2017, s. 65-71). Wynika z nich również, że produktywność pracy w rolnictwie ściśle wiąże się z powierzchnią gospodarstw rolnych. Gospodarstwa małe mają niewielkie zasoby ziemi i zazwyczaj występuje tu brak wolnego kapitału, lecz charakteryzują je największe nakłady pracy na jednostkę powierzchni użytkowanych gruntów. Przekłada się to na niską produktywność pracy. Na podstawie danych z tabeli 1 wykazano, że wzrostowi wielkości ekonomicznej gospodarstw towarzyszył wzrost średniej powierzchni UR. Fan i Chan-Kang (2005, s. 135-146) wykazali ponadto, że wzrost produktywności pracy jest możliwy albo przez wzrost produktywności ziemi, albo przez poprawę relacji pomiędzy czynnikiem ziemi i pracy. 
Wicki (2019, s. 287-296), analizując gospodarstwa rolne w Polsce, również dowiódl, że wielkość ekonomiczna gospodarstw jest jednym z najważniejszych czynników wpływających na ich produktywność, w tym na produktywność pracy. Podkreślił, że wielkość gospodarstw determinuje zdolność do inwestowania i wprowadzania postępu technicznego, osiągania korzyści skali zarówno wewnętrznych, jak i zewnętrznych, a także osiągania wyższej produktywności. Z badań tego autora wynika, że wraz ze wzrostem wielkości ekonomicznej zwiększa się nie tylko produktywność czynników produkcji, lecz także wydajność w produkcji roślinnej i zwierzęcej oraz intensywność reprodukcji majątku. Zasadne są zatem przekształcenia strukturalne ukierunkowane na procesy koncentracji w rolnictwie. Wśród przyczyn zróżnicowania produktywności pracy w rolnictwie wymienia się też jakość zasobów pracy związaną z kapitałem ludzkim, który może być wyrażany przez poziom wykształcenia osób zarządzających gospodarstwami rolnymi (Marcysiak, 2007, s. 397-405; Giannakis \& Bruggeman, 2018, s. 94-106). Z badań Nowak i Kijka (2016, s. 16-21) wynika, że kapitał ludzki aproksymowany poziomem wykształcenia ma pozytywny wpływ na przeciętną i marginalną produktywność pracy w gospodarstwach rolnych. Z kolei Józwiak (2015, s. 42) dowiódł, że w gospodarstwach z kierownikiem o niższym poziomie wykształcenia trudniejsze jest dostosowanie się do gorszych warunków gospodarowania.

Badania wykazały także zależność technicznego uzbrojenia pracy i produktywności pracy w gospodarstwach rolnych. Potwierdzają to m.in. badania Poczty, Średzińskiej i Pawlak (2008, s. 379-387). Wynika z nich, że w krajach o korzystnych wartościach wskaźnika technicznego uzbrojenia pracy produktywność w gospodarstwach rolnych z pola obserwacji FADN jest bardzo wysoka. Analogicznie niskie wyposażenie pracy w kapitał skutkuje niską efektywnością jej wykorzystania.

\section{Zakończenie}

Celem przeprowadzonych badań była ocena poziomu produktywności pracy w grupach gospodarstw rolnych o różnej wielkości ekonomicznej. Wykazano, że gospodarstwa najsłabsze ekonomicznie, tj. wytwarzające od 2 do 8 tys. euro produkcji standardowej, osiągnęły najniższy poziom produktywności pracy. W $2017 \mathrm{r}$. stanowiła ona zaledwie $23,7 \%$ średniego jej poziomu dla całej populacji badanych gospodarstw rolnych. Wraz z przechodzeniem do coraz wyższych klas wielkości ekonomicznej produktywność pracy rośnie. Klasa 6 odznaczała się wprawdzie niższym poziomem produktywności pracy niż klasa 5 , jednak był on prawie trzykrotnie wyższy niż średnio w całej badanej populacji. Oznacza to, że siła ekonomiczna gospodarstw determinuje efektywność wykorzystania czynnika pracy. Stanowi to przesłankę do intensyfikowania przekształceń strukturalnych w rolnictwie. Badania potwierdziły również związek poziomu produktywności pracy z poziomem jej technicznego uzbrojenia. Wskazuje to z jednej strony na potrzebę optymalizacji zasobów pracy w rolnictwie, z drugiej zaś na konieczność procesów modernizacyjnych. 
Nie wyczerpuje to możliwości oceny produktywności pracy badanych grup gospodarstw, stanowi jednak wstępny etap badań w tym zakresie. Dalsze badania powinny wykorzystać inne możliwe metody pomiaru produktywności oraz uwzględnić większy zakres determinant poprawy jej poziomu. Zasadne jest też prowadzenie badań w odniesieniu do grup gospodarstw wydzielonych ze względu na prowadzony kierunek produkcji, który w istotny sposób może wpływać na poziom produktywności pracy.

\section{Bibliografia}

Abramczuk, Ł., Chlebicka, A., Czułowska, M., Jabłoński, K., Józwiak, W., ..., \& Żekało, M. (2016). Przedsiębiorstwo i gospodarstwo rolne wobec zmian klimatu i polityki rolnej. Warszawa: IERiGŻ-PIB.

Bokusheva, R., \& Čechura, L. (2017). Evaluating dynamics, sources and drivers of productivity growth at the farm level. OECD Food, Agriculture and Fisheries Papers, 106. doi:10.1787/18156797

Czyżewski, A., \& Kryszak, Ł. (2016). Współzależności międzygałęziowe w sektorze rolnym w świetle modelu input-output a poziom finansowego wsparcia rolnictwa w wybranych krajach. Zeszyty Naukowe SGGW w Warszawie. Problemy Rolnictwa Światowego, 16(31).

Čechura, L., Grau, A., Hockmann, H., Kroupová, Z., \& Levkovych, I. (2014). Total Factor Productivity in European Agricultural Production. Leibniz Institute of Agricultural Development in Transition Economies (IAMO), Working Paper no. 9, October.

European Commission. (2009). European Competitiveness Report 2008. Brussels.

FADN EU Database. Pobrane z: https://ec.europa.eu/agriculture/rica/database/database_en.cfm

Fan, S., \& Chang-Kang, C. (2005). Is small beautiful? Farm size, productivity, and poverty in Asian agriculture. Agricultural Economics, 32 (Suppl. 1). doi:10.1111/j.0169-5150.2004.00019.x

Floriańczyk, Z., Osuch, D., \& Płonka, R. (2018). Wyniki Standardowe 2017 uzyskane przez gospodarstwa rolne uczestniczace w Polskim FADN. Cz. 1: Wyniki Standardowe. Warszawa: IERiGŻ-PIB.

Gałecka, A. (2017). Efektywność gospodarstw rolnych w Polsce w latach 2012-2015 w zależności od ich wielkości ekonomicznej. Roczniki Naukowe SERiA, 19(5). doi:10.5604/01.3001.0010.6207

Giannakis, E., \& Bruggeman, A. (2018). Exploring the labour productivity of agricultural systems across European regions: A multilevel approach. Land Use Policy, 77. doi:10.1016/j.landusepol.2018.05.037

Gołaś, Z. (2010). Wydajność i dochodowość pracy w rolnictwie w świetle rachunków ekonomicznych dla rolnictwa. Zagadnienia Ekonomiki Rolnej, 3(324).

Góral, J., \& Rembisz, W. (2017). Wydajność pracy i czynniki ją kształtujące w polskim rolnictwie w latach 2000-2015. Wieś i Rolnictwo, 4(177).

Grochowska, R., \& Mańko, S. (2014). Produktywność gospodarstw rolnych w Polsce na tle innych krajów. Zeszyty Naukowe SGGW w Warszawie. Problemy Rolnictwa Światowego, 14(29/1).

GUS. (2018a). Rocznik statystyczny rolnictwa. Warszawa.

GUS. (2018b). Rocznik statystyczny województw. Warszawa.

Jezierska-Thöle, A. (2012). Zróżnicowanie przestrzenne gospodarstw rolnych Polski i Niemiec według liczby i grup wielkościowych. Studia Obszarów Wiejskich. Planowanie Rozwoju Przestrzeni Wiejskiej, 29.

Józwiak, W. (red.). (2015). Przedsiębiorstwo i gospodarstwo rolne wobec zmian klimatu i polityki rolnej. Warszawa: IERiGŻ-PIB.

Kusz, D., \& Misiak, T. (2017). Wpływ technicznego uzbrojenia pracy i postępu technicznego na wydajność pracy w rolnictwie. Roczniki Naukowe SERiA, 19(2). doi:10.5604/01.3001.0010.1177

Latruffe, L. (2010). Competitiveness, productivity and efficiency in the agricultural and agri-food sectors. OECD Food, Agriculture and Fisheries Papers, 30. doi:10.1787/5km91nkdt6d6-en 
Madau, F.A., Furesi, R., \& Pietro, P. (2017). Technical efficiency and total factor productivity changes in European dairy farm sectors. Agricultural and Food Economics, 5(17). doi:10.1186/s40100-017-0085-x

Marcysiak, A. (2007). Cechy jakościowe zasobów pracy jako czynnik różnicujący poziom dochodu z gospodarstwa rolniczego. Zeszyty Naukowe SGGWw Warszawie. Problemy Rolnictwa Światowego, 2(17).

Marcysiak, A., \& Marcysiak, A. (2015). Wpływ wielkości ekonomicznej gospodarstw na zakres wsparcia środkami wspólnej polityki rolnej Unii Europejskiej. Roczniki Naukowe SERiA, 17(4).

Mikołajczyk, J. (2011). Wydajność pracy w towarowych gospodarstwach rolnych wg typów rolniczych i regionów. Roczniki Naukowe SERiA, 13(3). doi:10.15804/ksm201117

Mrówczyńska-Kamińska, A. (2012). Wydajność pracy w gospodarce żywnościowej w Polsce i Niemczech. Roczniki Ekonomii Rolnictwa i Rozwoju Obszarów Wiejskich, 99(2).

Niezgoda, D. (2009a). Uwarunkowania rentowności gospodarstw rolnych zróżnicowanych pod względem ich wielkości ekonomicznej. Roczniki Nauk Rolniczych. Seria G, 96(4).

Niezgoda, D. (2009b). Zróżnicowanie dochodu w gospodarstwach rolnych oraz jego przyczyny. Zagadnienia Ekonomiki Rolnej, 1(318).

Novotná, M., \& Volek, T. (2016). The significance of farm size in the evaluation of labour productivity in agriculture. Acta Universitatis Agriculturae et Silviculturae Mendelianae Brunensis, 64(1). doi:10.11118/actaun201664010333

Nowak, A., \& Kijek, T. (2016). The effect of human capital on labour productivity of farms in Poland. Studies in Agricultural Economics, 118. doi:10.7896/j.1606

Orłowska, M.J. (2014). Regionalne zróżnicowanie potencjału oraz efektywności czynników produkcji gospodarstw rolniczych w Polsce w świetle FADN. Roczniki Naukowe SERiA, 16(1).

Patra, S., \& Nayak, S.R. (2012). A theoretical study on the relationship between wages and labor productivity in industries. International Journal of Economics and Research, 3(3).

Poczta, W., Średzińska, J., \& Pawlak, K. (2008). Sytuacja finansowa gospodarstw rolnych krajów UE sklasyfikowanych według ich wyników produkcyjno-ekonomicznych. Zeszyty Naukowe SGGWw Warszawie. Problemy Rolnictwa Światowego, 4(19).

Rembisz, W., \& Bezat-Jarzębowska, A. (2013). Ekonomiczny mechanizm kształtowania dochodów producentów rolnych. Warszawa: IERiGŻ-PIB.

Skarżyńska, A. (2019). Koszty jednostkowe i dochody wybranych produktów w 2017 roku - wyniki badań w systemie AGROKOSZTY. Zagadnienia Ekonomiki Rolnej, 2(359). doi:10.30858/zer/109928

Sobczyński, T. (2010). Wydajność pracy a poziom wsparcia gospodarstw rolniczych w Polsce na tle UE. Roczniki Nauk Rolniczych. Seria G, 97(3).

Wicki, L. (2016). Zmiany produktywności czynników wytwórczych w polskim rolnictwie. Zeszyty Naukowe SGGW. Ekonomika i Organizacja Gospodarki Żywnościowej, 116. doi:10.22630/EIOGZ.2016.116.52

Wicki, L. (2019). Size vs effectiveness of agricultural farms. Annals PAAAE, 21(2). doi:10.5604/01.3001.0013.2212 